\title{
HA2 glycopolypeptide of influenza A virus and antiviral immunity
}

\author{
E. VAREČKOVÁ, V. MUCHA, F. KOSTOLANSKÝ
}

Institute of Virology, Slovak Academy of Sciences, Dúbravská cesta 9, 84505 Bratislava, Slovak Republic

\begin{abstract}
Summary. - Influenza A viruses (IAVs) cause acute respiratory infections in humans against which an effective prevention has not yet been developed due to their high variability and broad host specificity. The permanent threat of arising new influenza pandemic is represented by avian viruses which after their interspecies transmission can cause a disease with a devastating impact on humans lacking the specific immunity. Since the current vaccines inducing virus-neutralizing $(\mathrm{VN})$ antibodies are targeted at a variable globular part of hemagglutinin (HA), their efficacy is limited and they need permanent updating. On the other hand, conserved IAV antigens such as proton channel M2, membrane protein M1 or nucleoprotein (NP) do not induce $\mathrm{VN}$ antibodies, but they do induce heterosubtypic protection resulting in the reduction of virus replication and an improved recovery from the disease. From this point of view recent attention has also been focused on the conserved part of HA, its HA2 glycoprotein (HA2). The main aspects revealing a contribution of HA2 gp to protective immunity are discussed in this review.
\end{abstract}

Keywords: influenza A infection; HA2 glycopolypeptide; immune protection; monoclonal antibodies

\section{Contents:}

1. Introduction

2. The role of IAV HA in the immune response

2.1 Structure of HA

2.2 $\mathrm{HA}$ as an inductor of immune response

3. Antigenic structure of HA2

4. Biological activity of HA2-specific antibodies

4.1 Inhibition of fusion activity of HA mediated by HA2specific MAbs

4.2 Protection from lethal IAV infection mediated by HA2specific MAbs

5. HA2 as an immunogen suitable for the preparation of a cross-protective vaccine

5.1 Cross-protective potential of HA2 can be enhanced using a suitable vector

6. Conclusion

E-mail: viruevar@savba.sk; phone: 421-2-59302427.

Abbreviations: $\mathrm{APC}=$ antigen-presenting cells; $\mathrm{CTL}=$ cytotoxic $\mathrm{T}$ cells; EHA2 = HA2 ectodomain; HA = hemagglutinin; HA0 = HA precursor; IAV = influenza A virus; IFN = interferon; IL = interleukin; $\mathrm{MAb}=$ monoclonal antibody; $\mathrm{RBS}=$ receptor-binding site; $\mathrm{RT}=$ respiratory tract; TLR $=$ Toll-like receptor; NA $=$ neuraminidase; $\mathrm{NP}=$ nucleoprotein; p.i. $=$ post infection; $\mathrm{TNF}-\alpha=$ tumor necrosis factor alpha; $\mathrm{VN}$ = virus-neutralizing

\section{Introduction}

Influenza A viruses (IAVs) pose acute and worldwide spread of respiratory disease in humans. Due to their high variability, IAVs cause repeated epidemics or pandemics. The course of the disease caused by an IAV is controlled by the host immune system which determines the severity of the illness (Murphy and Clements, 1989; Tamura and Kurata, 2004). In humans, the infection starts by virus attachment to the epitelial cells of the upper respiratory tract (RT), where productive virus replication proceeds. The infection induces mechanisms of native and adaptive immunity. In the early stage of infection, IAV is recognized by Toll-like receptors (TLR). TLR3s recognize viral dsRNA in epithelial cells of upper and lower RT, while TLR7s recognize viral ssRNA mainly in acidic compartments of endosomes, where virus is internalized after its attachment to target cells. Proinflammatory cytokines, interferon (IFN) type I, tumor necrosis factor alpha (TNF- $\alpha$ ), interleukins 6 and 12 (IL-6, IL-12), and chemoattractive chemokines with antiviral effect are subsequently produced. They can all directly affect the infected cells. High levels of IFN type I, produced simultaneously in the lymph nodes, spleen and liver influence local as well as systemic antiviral immunity. IFN type I activates the differentiation of naive 
$\mathrm{CD}^{+}$T-cells to Th1 effectors producing high levels of IFN- $\gamma$ and thus starting the adaptive immune response. IFN- $\gamma$ in synergism with other cytokines increases their direct antiviral effect and on the other hand, upregulates expression of TLR by antigen presenting cells (APC) and lung epithelial cells. Once the infection is established, mechanisms of adaptive immunity are involved. Infected host cells are recognized and subsequently eliminated predominately by specific effector $\mathrm{CD} 8^{+} \mathrm{T}$ lymphocytes possessing cytolytic activity (Boon et al., 2004). They are activated between day 3-5 post infection (p.i.), reaching a maximum around day 7-9 p.i. Simultaneously, on day 5-7 p.i., production of specific antibodies begins. The specific antibody level increases up to day 21 and, in case of repeated infection, memory B-cells ensure a very rapid and robust specific antibody response. In influenza infection, the specific humoral immunity plays the most important role. However, a high variability of IAVs due to the error-prone viral RNA-dependent RNA polymerase enables them to evade the host immune mechanisms leading to repeated epidemics. From the point of view of protective immunity against influenza, the antibodies specific to the surface antigens, HA and neuraminidase (NA), are the most important. HA-specific antibodies are crucial, because they have virus-neutralizing activity. Another strong immunogen is surface glycoprotein NA which induces antibodies inhibiting the esterase activity of NA and consequently preventing the virus release from the cell and the spread of infection in the organism. The NA-specific antibodies however do not prevent infection completely (Johanson et al., 1989; Murphy and Clements, 1989; Mozdanowska et al., 1999). During infection, the antibodies are induced also against another surface antigen, M2 proton channel. In convalescent sera, their level is very low or even undetectable (Gerhard 2001). However, due to the conservation of M2 among IAVs of various HA subtype, attention has been focused on this protein, especially on its ectodomain (eM2) (Mozdanowska et al., 1999; Neirynck et al., 1999; Frace et al., 1999). Enhanced levels of eM2-specific antibodies, produced following a targeted immunization with eM2, were shown to be protective (Mozdzanowska et al., 2003; Fiers et al., 2004; Mozdzanowska et al., 2007). Moreover, during IAV infection, antibodies against internal proteins NP, PB1, and PA have also been detected, but no unambiguous protective effect has been attributed to them. However, these proteins comprise immunodominant MHC-I- restricted T-epitopes which induce virus-specific cytotoxic T cells (CTLs) contributing to heterosubtypic immunity against influenza (Grebe et al., 2008). The most effective of them are NP-specific CTLs (Yewdell et al., 1985; Gerhard, 2001; Staneková and Varečková, 2010, Grant et al., 2013).

\section{The role of influenza virus $\mathrm{HA}$ in the immune response}

\subsection{Structure of $H A$}

Influenza virus HA is a glycoprotein forming on the virus surface spikes composed of three identical HA molecules inserted into the virion envelope by their C-termini. HA plays a crucial role during virus entry into the cell thus determining the initiation of infection. It is responsible for the attachment of virus to the sensitive target cells and the fusion of viral and endosomal membranes. HA is synthesized on ribosomes of the endoplasmic reticulum of infected cells as a precursor (HA0) molecule undergoing trimerization and postranslation modification, particularly glycosylation and acylation on its C-terminus (Skehel and Wiley, 2000). HA0 is postranslationally cleaved by host proteases into two glycopeptides, HA1 (heavy chain) and HA2 (light chain). In a HA trimer, HA1 and HA2 remain connected via disulphide bond (Klenk et al., 1975; Lazarowitz and Chopin, 1975). Three HA monomers are bound by intermolecular non-covalent bonds thus forming a mature HA molecule. A highly variable HA1 forms a globular head on which a receptor-binding site (RBS) is localized, composed of residues conserved in all subtypes of influenza virus, particularly aa 98, 134-138, 153, 183, 190, 194, 195, 224-228 (Weis et al., 1988; Watowich et al., 1994; Eisen et al., 1997). The corresponding receptor on the cell surface is sialic acid connected by glycosidic bond to glycoproteins or glycoplipids of the cell membrane. Human viruses preferentially bind to terminal sialic acid bound to galactose by the Sia( $(2-6)$ Gal glycosidic bond, while avian viruses preferentially recognize sialic acid bound by the Sia(a2-3) Gal bond. Both receptors are present on the surface of swine epithelial cells and pigs can be infected by influenza viruses of both, human or avian origin, even simultaneously. A mixed infection with viruses of different subtype/origin enables a rearrangement of viral RNA segments which can result in the appearance of potentially pandemic reassortant viruses that have not occurred in humans before.

Another important role of $\mathrm{HA}$ is the mediation of fusion of viral envelope and endosomal membrane, for which the relatively conserved part of HA, the HA2 gp is responsible. At neutral $\mathrm{pH}$, the fusion peptide (the $\mathrm{N}$-terminus of HA2) is buried in a pocket of charged amino acid residues formed by trimeric coiled coil HA stem. At low $\mathrm{pH}(\sim 5.0)$ in the endosomal cell compartment, intermolecular bonds in the HA trimer are released and the fusion peptide is exposed from its buried position in the trimer and inserted into the target membrane (Skehel et al., 1982; Doms and Helenius, 1986; Carr et al., 1993; Hughson, 1995). 
Pre-fusion and post-fusion conformations of HA have been defined by X-ray analysis (Chen et al., 1999; Knossow et al., 2002). It has been proven that a small population (3-7\%) of HA spikes in native virions could be spontaneously and without influence of low $\mathrm{pH}$, restructured into the post-fusion form (Kostolanský et al., 1988; Varečková et al., 1993). The conformation change is temperature- dependent, i.e. an increased temperature accelerates the HA refolding (Yewdell et al., 1983; Skehel and Wiley, 2000; Vaccaro et al., 2005). The low $\mathrm{pH}$-change of HA is irreversible and is accompanied by modified antigenic properties (Daniels et al., 1983; Yewdell et al., 1983; Webster et al., 1983). It should be stressed however that the fusion activation cannot occur in the precursor HAO and that virions with an uncleaved HAO molecule are non-infectious, as they cannot mediate the fusion of viral and endosomal membranes. This means that fusion inhibition could be a possible mechanism to prevent infection and can play a role in antiviral immunity.

\subsection{HA as an inductor of immune response}

HA is the main inductor of specific antibodies. It induces a spectrum of antibodies, a part of which are targeted towards epitopes near the receptor-binding site (Grehard et al., 2001). These antibodies, after binding to the receptor-binding site (RBS), block virus attachment to the cell surface (Skehel and Wiley, 2000). When their binding affinity and concentration are high enough, they can prevent virus infection (Kostolanský et al., 2000). The effectivity of these antibodies to neutralize virus decreases with the distance of their binding from RBS. The antibodies bound to HA distantly from RBS do not neutralize virus, because they do not block the virus attachment to the cell, but they can influence subsequent steps of the virus replication cycle by other mechanisms (Vanlandschoot et al., 1998, Edwards and Dimmock, 2000, 2001; Gerhard, 2001). On the variable globular HA1 gp, 5 antigenic sites were defined (Wiley et al, 1981; Wilson et al., 1981; Caton et al., 1982; Skehel and Wiley., 2000). They were localized on the HA molecule by X-ray structural and sequence analyses of escape mutants, selected by virusneutralizing monoclonal antibodies (MAbs). A similar process, named „antigenic drift" occurs in human population when epidemic IAV strains under the selection pressure of antibodies, present in humans since previous IAV infections, undergo antigenic changes. Such changes resulting in viable mutant viruses are one of several prerequisites for high variability of IAVs and are responsible for the efficacy restriction of current vaccines (Palese and Garcia-Sastre, 2002; Palese, 2006; Arnon, 2006; Luke and Subbarao, 2006; Gerhard et al., 2006; Osterhaus et al., 2011).

At present, attention is being focused on the HA2 gp forming the stem of the HA trimer. HA2 gp is much more antigenically stable than HA1 gp (Both et al., 1983; Becht et al., 1984; Russ et al., 1987; Sanchez-Fauquier et al., 1987; Sanchez-Fauquier et al., 1991, Varečková et al., 2008). In the native form, HA2 is covered by the globular part of the HA1 molecule and its accessibility is sterically restricted. Due to its localization, the role of HA2 gp in the anti-influenza immune response was regarded for a long time as negligible and HA2 gp was not considered to be a part of the antigenic structure of HA. The first evidence of interaction of HA2 gp with the host immune system was reported by Russ et al. (1978) who proved the presence of both anti-HA1 and anti-HA2 antibodies in rabbit immune sera induced by intact influenza virus and purified HA as well. Next, important evidence came from the analysis of human convalescent sera when Styk et al. (1979) detected both HA1- and HA2specific antibodies in sera of humans overcoming influenza infection. The immunogenicity of HA2 was also confirmed later by Brown et al. (1980). On the other hand it was established that HA2-specific antibodies do not neutralize the virus and do not agglutinate erythrocytes (Becht et al., 1984, Russ et al., 1987). Shortly after this, more evidence that HA2 plays a role in the host-immune response was reported by Wabuke-Bunotti et al. $(1983,1984)$ who described HA2specific MHC-I-restricted CTLs. Results on the existence of HA2-specific CTLs were also described by other authors several years later (Gould et al., 1987; Kuwano et al., 1988; Braciale et al., 1989; Mbawuike et al., 1994; Saikh et al., 1995; Masaki et al., 2000). Simultaneously, T-helper cells recognizing HA2 were described (Katz et al., 1985; Gerhard et al., 1991; Jackson et al., 1994). However, the role of the anti-HA2 immune response during infection remained unresolved at that time.

\section{Antigenic structure of HA2}

After developing hybridoma technology, HA2-specific MAbs were prepared in several laboratories (SanchezFauquier et al., 1987; Russ et al., 1987). These MAbs have become powerful research tools for better characterization of HA2 as an antigen and brought new insight into its role in virus-cell membrane fusion.

The antigenic structure of HA2 was described for the first time using a panel of seven HA2-specific MAbs (Russ et al., 1987; Varečková et al., 2003a). Four different antigenic sites on HA2 were determined on the basis of competitive relationships among these MAbs in radioimmunoassay and their binding to various HA fragments. Particular antigenic sites were localized to the following amino acid regions on HA2: site I to aa1-38 at the N-terminus, sites II and IV to aa 125-175, and site III to aa 38-112. The sites II and IV, localized to the same region, were distinguished as they did not exhibit mutual competition 


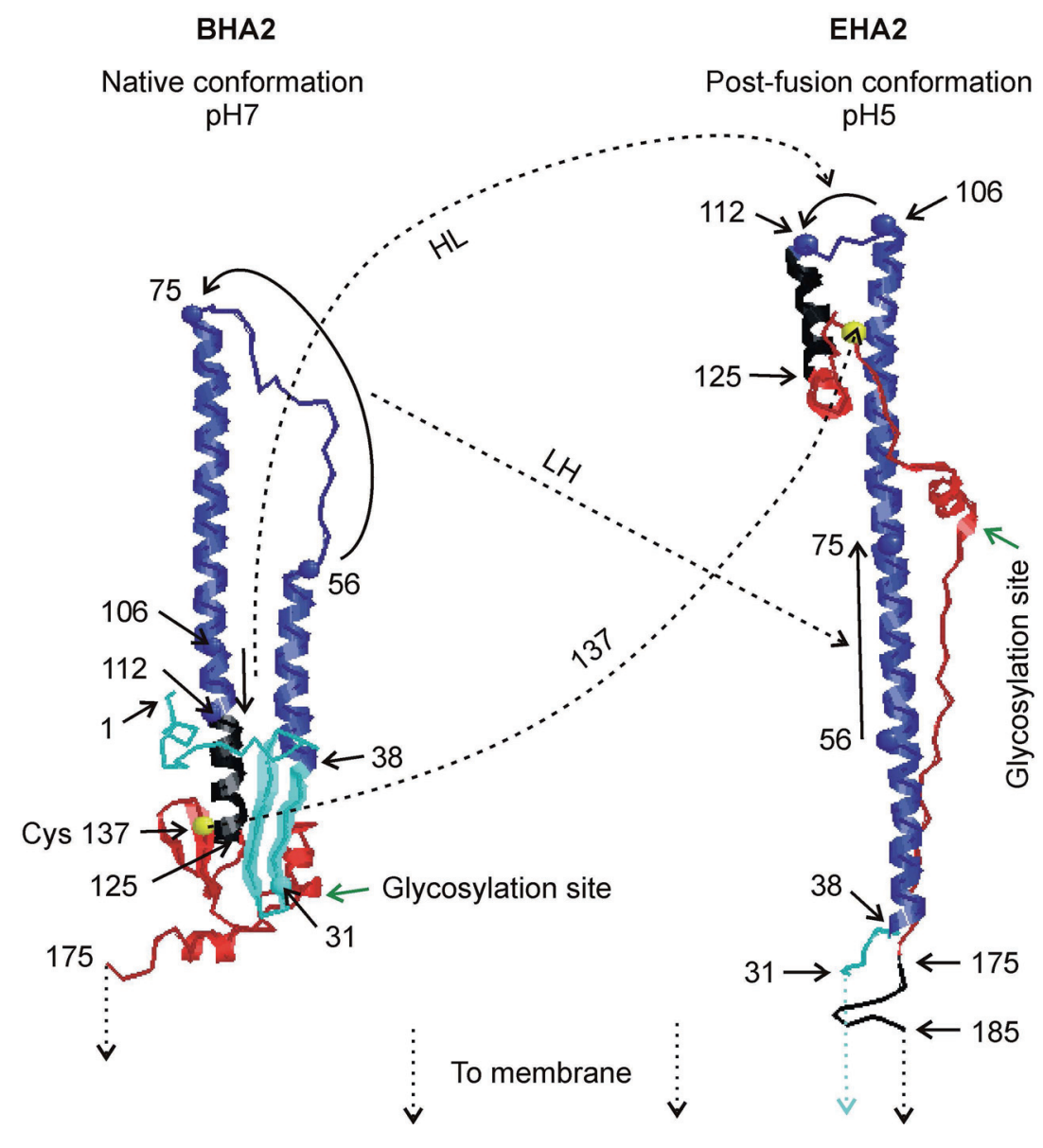

Fig. 1

Antigenic structure of HA2 as determined using HA2-specific monoclonal antibodies

The regions to which the antigenic sites are localized are depicted on both native and post-fusion conformation of HA2. Site I of aa 1-38 (cyan), site II of aa 125-175 (red), site III of aa 38-112 (dark blue), and site IV of aa 125-175 (red). Sites II and IV act independently though they are localized to the same region (red) and are separated by a glycosylation site. For a ribbon presentation of the molecules the RCSB Protein Data Bank files 1 HGF.pdb of the bromelain-digested hemagglutinin of A/Aichi/68 (H3N2) virus (Wiley and Skehel, 1977) and 1QU1.pdb of EHA2 construct (Chen et al., 1999) were used. A computer program RasMol was used for molecular graphics visualization. $\mathrm{HL}=$ change helix $\rightarrow$ loop, $\mathrm{LH}=$ change loop $\rightarrow$ helix, BHA2 $=\mathrm{HA} 2$ part of bromelain cleaved hemagglutinin.

and their reactivity with IAVs of $\mathrm{H} 3, \mathrm{H} 4$, and $\mathrm{H} 5$ subtypes differed (Varečková et al., 2003a, 2008).

The accessibility of all these antigenic sites in the native $\mathrm{HA}$ form is low. However, after the fusion activation of HA at low $\mathrm{pH}$ in endosomes and its extensive conformation change, the antigenic sites on HA2 become more accessible to antibodies (Hughson, 1995; Chen et al., 1995; Wharton et al., 1995). These conformation changes affect all four antigenic sites on HA2 as the binding of the MAbs to these sites increase (Fig. 1) (Varečková et al., 2003a).

The fusion peptide comprising site I (recognized by MAb CF2) is in native form inserted into a charged pocket in the intersubunit space of the HA stem and, due to the conformation change triggered by low $\mathrm{pH}$, is released and exposed outwards from the pocket. This thermodynamically metast- able conformation is stabilized by insertion of the $\mathrm{N}$-terminus of HA2 into the cell membrane, initiating the fusion process. Alternatively, it can be inserted into the virion membrane which results in irreversible inactivation of HA fusion potential (Skehel and Wiley, 2000). The region of aa 125-175 of HA2 comprising sites II and IV (recognized by MAbs IIF4 and FC12/FE1, respectively), originally folded at the proximal end of HA stem of native $\mathrm{HA}$ trimer, with low $\mathrm{pH}$ is stretched along almost the full length of the molecule. After low $\mathrm{pH}$ treatment, this part of HA2 is restructured and acquires an opposite orientation. The part of the region of aa 38-112 comprising site III (recognized by MAb CB8) forms in the native molecule a helix consisting of aa 38-58 and aa 75-112 and a loop with aa 56-75. At low $\mathrm{pH}$, the loop is restructured into a helix and a new structure with a loop between aa 106 
and aa 112 is formed. The structural changes in all antigenic sites are reflected in increased reactivity of MAbs recognizing corresponding HA2 epitopes observed mainly with MAb IIF4 binding to site II. This region was also considered to be the most immunogenic part of HA2 (Staneková et al., 2012). Furthermore, the regions comprising sites I and III exhibited slightly increased binding of the corresponding MAbs after the structural rearrangement of $\mathrm{HA}$ at low $\mathrm{pH}$.

Consequently, some HA2-specific MAbs represent suitable probes for monitoring structural changes of HA (Wharton et al., 1995; Chen et al., 1995; Vanlandschoot et al., 1998; Leikina et al, 2001; Langley et al., 2010). The structural changes in HA triggered by low $\mathrm{pH}$ could be important also from the point of view of interaction of HA2 with the antibodies induced in the immunized or infected organism.

\section{Biological activity of HA2-specific antibodies}

HA-specific antibodies influence virus replication by different mechanisms (Edwards and Dimmock, 2000, 2001). They can block virus attachment to the cell surface of epitelial cells in the upper respiratory tract, resp. in vitro on the cell surface with the appropriate receptors and can block virus entry. Virus receptors, glycoproteins or glycoplipids with terminal sialic acid are also present on red blood cells, thus agglutination of erythrocytes mediated by virus (hemagglutination) can be used for monitoring of virus-neutralizing activity of HA-specific antibodies. HA-specific antibodies which bind distantly from the RBS mediate inhibition of virus replication by other mechanisms. Their binding to HA does not block virus attachment to the cell surface, but prevents the fusion of virus and cell membranes (Okuno et al., 1993, 1994; Vanlandschoot et al., 1998; Imai et al., 1998; Varečková et al., 2003a; Throsby et al, 2008; Wang et al., 2010a), which can be monitored using various systems such as fusion of cells expressing HA on their surface (Huang et al., 1981; White et al., 1982; Godley et al., 1992), lysis of red blood cells with the virus attached to their surface and their subsequent exposition to low pH (Norby and Gollmar, 1975; Maeda and Ohnishi, 1980) and the most sensitive method, fusion of the virus with fluorescently labelled liposomes monitored by resonance energy transfer method (Struck et al., 1981; Wharton et al., 1986).

\subsection{Inhibition of fusion activity of HA by HA2-specific MAbs}

It has been shown that some HA2-specific MAbs inhibit polykaryon formation in cells expressing HA on their surface, virus-mediated hemolysis and virus-liposome fusion (Varečková et al., 2003a). The most effective was the antibody recognizing aa 1-38 of the N-terminus of HA2, which inhibited the fusion in all three experimental systems and also virus replication in vitro (Varečková et al., 2003b). Later, other MAbs, specific to conformation epitopes on the HA stem comprising HA2 and HA1, were shown to inhibit the virus fusion. They sterically blocked the low $\mathrm{pH}$-triggered conformation change and so prevented the activation of fusion potential of $\mathrm{HA}$ and consequently the virus replication. The intersubtype amino acid sequence conservation in HA2 (Nobusawa et al., 1991) and the inhibition of fusion activity or virus replication by HA2-specific antibodies together with their intersubtype reactivity draw attention to $\mathrm{HA} 2$ as an immunogen potentially able to induce cross-protection from influenza.

\subsection{Protection of mice from lethal IAV infection mediated} by HA2-specific MAbs

It could be supposed that there is a close correlation between the inhibition of fusion in vitro and that of virus replication in vivo. The first experiments of passive immunization with fusion-inhibiting antibodies specific to HA2 gp revealed the protective effect on lethal influenza infection with influenza A virus of both homologous and of heterologous HA subtype (Gocník et al., 2007; Prabhu et al., 2009). The most effective were antibodies recognizing the fusion peptide, the conserved part of HA. These experiments

Table 1. Fusion-inhibition activity of HA2-specific monoclonal antibodies

\begin{tabular}{|c|c|c|c|c|c|}
\hline Antigenic site & MAb & $\begin{array}{c}\text { Inhibition of polykary- } \\
\text { on formation }\end{array}$ & $\begin{array}{c}\text { Inhibition of virus- } \\
\text { liposome fusion }\end{array}$ & Inhibition of hemolysis & $\begin{array}{l}\text { Index of protectivity } \\
\text { in vivo }\end{array}$ \\
\hline \multirow[t]{3}{*}{ I } & BB8 & - & \pm & + & ND \\
\hline & EB12 & - & + & \pm & ND \\
\hline & CF2 & + & + & + & 1.00 \\
\hline II & IIF4 & - & \pm & + & 0.88 \\
\hline III & CB8 & - & - & - & $0.00^{\mathrm{a}}$ \\
\hline \multirow[t]{2}{*}{ IV } & FC12 & - & \pm & \pm & ND \\
\hline & FE1 & - & - & - & 1.00 \\
\hline
\end{tabular}

The data originates from Varečková et al. (2003a) and Gocník et al. $(2007) .(+)=>50 \%$ inhibition; $( \pm)=25-50 \%$ inhibition; ND = not done. ${ }^{a}$ The course of infection worsened. 
showed that HA2-specific monoclonal antibodies with fusion inhibition activity reduced virus replication not only in vitro (Varečková et al., 2003b; Stropkovská et al., 2009), but also in vivo (Gocník et al., 2007) (Table 1).

Furthermore, it has been reported that MAbs recognizing conformational epitopes comprising both HA1 and HA2 simultaneously, inhibited the replication of virus in vitro and in vivo (Lipatov et al., 1997; Smirnov et al., 2000; Lim et al., 2008; Sui et al., 2009; Wang et al., 2010a; Lingwood et al., 2012). These MAbs inhibited IAV fusion activity by prevention of the conformational change of the HA trimer, i.e. inhibited the activation of the fusion potential of HA. These protective studies confirmed that HA2-specific MAbs can be used for therapeutic purposes against influenza. For this reason several human or humanized MAbs specific to the stem of HA trimer have recently been characterized as candidates for anti-influenza therapy (Throsby et al., 2008; Sui et al., 2009; Ekiert et al., 2009, 2011). The main prerequisite of HA-specific antibodies for protective activity is their high affinity of binding to the target epitope, ranging in order between nmol/l and pmol/l (Ekiert et al., 2012).

\section{HA2 as an immunogen suitable for preparation of cross-protective vaccine}

Analysis of human convalescent sera regarding the immunogenicity of particular HA2 epitopes has shown that during infection, some HA2 epitopes elicit a stronger antibody response than others, but are nevertheless all weak immunogens (Staneková et al., 2012). The low level of HA2-specific antibodies induced during infection would not be sufficient for protection from a severe infection with IAV of new HA subtype (Gerhard, 2001). However, as has been experimentally proven, a repeated immunization of mice with IAV of different subtype led to a marked increase in HA2-specific antibody response (Kostolanský et al., 2002). A targeted immunization with HA2 gp resulting in an increased level of HA2-specific antibodies of high affinity could improve recovery from the disease. Using an animal model, it has been shown that immunization with HA2, expressed by recombinant vaccinia viruses capable of inducing $\mathrm{T}$ - and B-cell immunity posed heteroprotection against infection with IAVs of $\mathrm{H} 3$ and $\mathrm{H} 1$ subtypes (Gocník et al., 2008). Similarly, repeated immunization with purified HA2 gp, produced in E. coli transformed with plasmids expressing the HA2 ectodomain (EHA2) with aa 23-185 in low pH-conformation (Janulíková et al., 2012) or HA2 peptides in native (neutral $\mathrm{pH}$ ) conformation (Bommakanti et al., 2010) protected mice against a lethal infection with IAVs of human and also of avian origin. Recently, many other systems expressing HA2 gp or the HA trimer stem leading to stimulation of protective immune response have been described (Steel et al., 2010; Ekiert et al., 2009, 2011, 2012).
5.1 Cross-protection potential of HA2 can be enhanced using a suitable vector

The cross-protective potential against influenza can be enhanced by a selection of peptides representing T- or B-cell epitopes, known to be conserved among different HA subtypes. Following insertion into suitable viral vectors or recombinant carrier proteins, they can be presented to immunocompetent cells leading to their specific activation and induction of humoral and cell cross-protective immunity (for reviews see Arnon, 2006; Staneková and Varečková, 2010; Osterhaus et al., 2011; Zhang, 2012). Recently, a detoxified adenylate cyclase toxin (CyaA) produced by gram-negative bacteria Bordetella pertussis has been described as a carrier for the presentation of various antigens (Sebo et al., 1991; Sakamoto et al., 1992; Guermonprez et al., 1999; Fayolle et al., 1996; Saron et al., 1997; Fayolle et al., 1999; Loucka et al., 2002; Simsova et al., 2004; Schlecht et al., 2004; Préville et al. 2005). It specifically binds to CD $11 \mathrm{~b} / \mathrm{CD} 18$ receptors on the surface of antigen presenting cells (APC) and penetrates into the cytosol (Benz et al.,1994). Passenger antigens (small peptides), inserted into the genetically detoxified CyaA following their proteasome processing, are presented on MHC I molecules and recognized by corresponding T-cells which are specifically activated. Moreover, the use of CyaA as a delivery system also allows for the presentation of a passenger antigen/peptide on MHC II molecules and to potentiating of the antigen-specific humoral immune response (Mascarell et al., 2005).

CyaA was used for the first time for presentation of IAV antigens, particularly of ectodomain of HA2 with aa 23-185 (Staneková et al., 2013). These experiments showed that $\mathrm{HA} 2$ can induce specific $\mathrm{T}_{\mathrm{c}}$-and $\mathrm{B}$-cell immunity resulting in in vivo cross-protection against IAVs of human $(\mathrm{H} 1, \mathrm{H} 3)$ and also avian (H7) origin. The cross-protective immune response was found to be broader than that induced by EHA2 in the presence of the Freund's adjuvant (Janulíková et al., 2012). The better cross-protectivity achieved by CyaA-HA2 immunization, in comparison to immunization with purified HA2, could be attributed to the specific T-cell immune response involved thanks to insertion of HA2 into CyaA toxoid enabling its presentation on MHC I molecules. The delivery system based on the presentation of IAV antigens to T- and B-cells by CyaA can be considered as one possibility to broaden cross-protection against influenza without the need for any adjuvant. It enables the combination of various conserved IAV peptides inducing protective immunity and could be helpful particularly in the case of the emergence of a new pandemic virus, which humans have not met before. Such an epitope-based vaccine could reduce the severity of disease caused by new pandemic viruses. It can be regarded as a useful alternative to current vaccines, the efficacy of which is limited due to 
the high IAV variability and time-consuming preparation of updated vaccines.

\section{Conclusion}

Prevention against influenza is based on the production of effective influenza vaccines inducing virus-neutralization antibodies, which are protective against circulating epidemic strain undergoing the antigenic drift. After several cases of human infections with viruses of avian origin in 1997 which represented the potential threat of new pandemic, a new strategy of vaccine preparation has been developed (Tamura et al., 2005). Better understanding of the correlates of immune protection and the role of T-cell-mediated immunity in heteroprotection against influenza has brought more complex insight into the designing of anti-influenza vaccines (Osterhaus et al., 2011; Kreijtz et al., 2011). Attention has been focused on the conserved antigens, mainly NP, M1 or M2, inducing protective immunity. To broaden the protection efficacy against IAV of various subtypes, novel approaches using adjuvants or vectors for antigen delivery such as recombinant viruses, or virus-like particles, bacterial expression systems, or plasmid DNA have been described (Fiers et al., 2004; Hillaire et al., 2011; Lillie et al., 2012). From many recent studies it can be concluded that HA2 gp, the conserved part of HA, can also be a good inductor of cross-protection. It has a complex antigenic structure and is able to induce protective antibody and $\mathrm{T}$-cell immune response. At present, peptides corresponding to HA2 epitopes inserted into the various vectors, or the complex trimer of HA2 stem are examined as inductors of cross-protection (Ekiert et al., 2009; Sui et al., 2009; Wang and Palese, 2009; Steel et al., 2010; Bommakanti et al., 2010; Wang et al., 2010b; Eckert and Kay, 2010; Krammer et al., 2012; Janulíková et al., 2012; Staneková et al., 2013). From these studies it can be proposed that HA2 fulfils the requirements to be a candidate for the construction of influenza vaccine with broader protection efficacy.

Acknowledgement. This work was supported by grants from the Slovak Research and Development Agency under the contract No. APVV-0250-10, No. DO7RP-0025-10 and by grants from the Scientific Grant Agency of the Ministry of Education of the Slovak Republic and Slovak Academy of Sciences VEGA 2/0176/12, 2/0100/13, and 2/0117/11.

\section{References}

Arnon R, Expert. Rev.Vaccines 6, 939-948, 2006.

Benz R, Maier R, Ladant D, Ullmann A, Sebo P, J. Biol. Chem. 269, 27231-27239, 1994.

Becht H, Huang RTC, Fleischer B, Boschek CB, Rott R, J. Gen. Virol. 65, 173-183, 1984. http://dx.doi.org/10.1099/0022$\underline{1317-65-1-173}$
Bommakanti G, Citron MP, Hepler RW, Callahan C, Heidecker GJ, Najar TA, Lu X, Joyce JG, Shiver JW, Casimiro DR, ter Meulen J, Liang X, Varadarajan R, Proc. Natl. Acad. Sci. USA 107, 13701-13706, 2010. http://dx.doi.org/10.1073/ pnas. 1007465107

Both GW, Sleigh MJ, Cox NJ, Kendal AP, J. Virol. 48, 52-60, 1983.

Boon AC, De Mutsert G, van Baarle D, Smith DJ, Lapedes AS, Fouchier RAM, Sintnicolaas K, Osterhaus ADME, Rimmelzwaan GF, J. Immunol.172, 2453-2460, 2004.

Braciale TJ, Sweetser MT, Morrison LA, Kittlesen DJ, Braciale VL, Proc. Natl. Acad. Sci. USA 86, 277-281, 1989. http:// dx.doi.org/10.1073/pnas.86.1.277

Brown LE, Dopheide TAA, Ward CW, White DO, Jackson DC, J. Immunol. 125, 1583-1588, 1980.

Carr, CM, Kim PS, 73, 823-832, 1993.

Caton AJ, Brownlee GG, Yewdell JW, Gerhard W, Cell 31, 417-427, 1982. http://dx.doi.org/10.1016/0092-8674(82)90135-0

Chen J, Wharton SA, Weissenhorn W, Calder L, Hughson FM, Skehel JJ, Wiley DC, Proc. Natl. Acad. Sci. USA 92, 12205-12209, 1995. http://dx.doi.org/10.1073/ pnas.92.26.12205

Chen J, Skehel JJ, Wiley DC, Proc. Natl. Acad. Sci. USA 96:89678972, 1999. http://dx.doi.org/10.1073/pnas.96.16.8967

Daniels RS, Douglas AR, Skehel JJ, Wiley DC, J. Gen. Virol. 64: 1657-1662, 1983. http://dx.doi.org/10.1099/0022-131764-8-1657

Doms RW, Helenius A, J. Virol. 60, 833-839, 1986.

Eckert DM, Kay MS, Proc. Natl. Acad. Sci. USA 107, 13563-3564, 2010. http://dx.doi.org/10.1073/pnas.1008672107

Edwards MJ, Dimmock NJ, Virology 278, 423-435, 2000. http:// dx.doi.org/10.1006/viro.2000.0631

Edwards MJ, Dimmock NJ, J. Gen. Virol. 82, 1387-1395, 2001.

Eisen MB, Sabesan S, Skehel JJ, Wiley DC, Virology 232, 19-31, 1997. http://dx.doi.org/10.1006/viro.1997.8526

Ekiert DA, Bhabha G, Elsliger MA, Friesen RH, Jongeneelen M, Throsby M, Goudsnith J, Wilson A, Science 324, 246-251, 2009. http://dx.doi.org/10.1126/science.1171491

Ekiert DC, Friesen RH, Bhabha G, Kwas T, Jongeneelen M, Zu W, Ophorst C, Cox F, Korse HJWM, Brandenburg B, Vogels R, Brakenhoff APJ, Kompier R, Koldijk MH, Cornelissen LAHM, Poon LL, Peiris M, Koudstaal W, Wilson IA, Goudsmit J, Science 333, 843-850, 2011. http://dx.doi. org/10.1126/science. 1204839

Ekiert D, Kashyap AK, Steel J, Rubrum A, Bhabha G, Khayat R. Lee JH, Dillon MA, O Neil RE, Faynboym AM, Horowitz M, Horowitz L, Ward AB, Palese P, Webby R, Lerner RA, Bhatt RR, Wilson IA, Nature 489, 526-536, 2012. http:// dx.doi.org/10.1038/nature11414

Fayolle C, Ladant D, Karimova A, Ullmann A, Leclerc C, J. Immunol. 162, 4157-4162, 1999.

Fiers W, De Fillette M, Birkett A, Neirynck S, Min Jou W, Virus Res. 103, 173-176, 2004. http://dx.doi.org/10.1016/j. virusres.2004.02.030

Frace AM, Klimov AI, Rowe T, Black RA, Katz JM, Vaccine 17, 2237-2244, 1999. http://dx.doi.org/10.1016/S0264410X(99)00005-5

Gerhard W, Curr. Top. Microbiol. Immunol. 260, 171-190, 2001. http://dx.doi.org/10.1007/978-3-662-05783-4 9 
Gerhard W, Haberman, AM, Scherle PA, Taylor AH, Palladino G, Caton AJ, J. Virol. 65, 364-372, 1991.

Gerhard W, Mozdzanowska K, Zharikova D, Emerg. Infect. Dis. 12, 569-573, 2006. http://dx.doi.org/10.3201/ eid1204.051020

Gocník M, Fislová T, Mucha V, Sládková T, Russ G, Kostolanský F, Varečková E, J. Gen. Virol. 89, 958-967, 2008. http:// dx.doi.org/10.1099/vir.0.83524-0

Gocník M, Fislová T, Sládková T, Mucha V, Kostolanský F, Varečková E, J. Gen. Virol. 88, 951-955, 2007. http:// dx.doi.org/10.1099/vir.0.82563-0

Grant E, Wu Ch, Chan KF, Eckle S, Bharadvaj M, Zou QM, Kedzierska K, Chen W, Immunol. Cell Biol. 91, 184-194, 2013. http://dx.doi.org/10.1038/icb.2012.78

Godley L, Pfeifer J, Steinhauer D, Ely B, Shaw G, Kaufmann R, Suchanek E, Pabo C, Skehel JJ, Wiley DC, Wharton S, Cell 68, 635-645, 1992. http://dx.doi.org/10.1016/00928674(92)90140-8

Gould KG, Scotney H, Townsend AR, Bastin J, Brownlee GG, J. Exp. Med. 166, 693-701, 1987. http://dx.doi.org/10.1084/ jem.166.3.693

Grebe KM, Zewdell JW, Bennink JR, Microb. Infect. 10, 1024-1029, 2008. http://dx.doi.org/10.1016/j.micinf.2008.07.002

Guermonprez P, Fayolle C, Rojas MJ, Rescigno M, Ladant D, Leclerc C., Eur. J. Immunol. 32, 3071-3081, 2002. http:// dx.doi.org/10.1002/1521-4141(200211)32:11<3071::AIDIMMU3071>3.0.CO;2-A

Hillaire MLB, Osterhaus ADME, Rimmelzwaan GF, J. Biomed. Biotechnol. volume?, pages?, 2011.

Huang RTC, Rott R., Klenk HD, Virology 110, 243-247, 1981. http:// dx.doi.org/10.1016/0042-6822(81)90030-1

Hughson FM, Curr. Biol. 5, 265-274, 1995. http://dx.doi. org/10.1016/S0960-9822(95)00057-1

Imai M, Sugimoto K, Okazaki K, Kida H, Virus Res. 53, 129-139, 1998. http://dx.doi.org/10.1016/S0168-1702(97)00143$\underline{3}$

Jackson DC, Drummer HE, Brown LE, Virology 198, 613-623, 1994. http://dx.doi.org/10.1006/viro.1994.1073

Janulíková J, Staneková Z, Mucha V, Kostolanský F, Varečková E, Acta Virol. 56, 169-76, 2012. http://dx.doi.org/10.4149/ av $201203 \quad 169$

Johanson BE, Bucher DJ, Kilbourne ED, J. Virol. 63, 1239-1246, 1989.

Katz JM, Laver JG, White DO, Unders EM, J. Immunol. 134, 616622, 1989.

Klenk HD, Rott R, Orlich M, Blodom J, Virology 68, 426-439, 1975. http://dx.doi.org/10.1016/0042-6822(75)90284-6

Knossow M, Gaudier M, Douglas A, Barrere B, Bizebard T, Barbey C, Gigant B, Skehel JJ, Virology 302, 294-298, 2002. http:// dx.doi.org/10.1006/viro.2002.1625

Kostolanský F, Styk B, Russ G., Arch. Virol. 101, 13-24, 1988. http:// dx.doi.org/10.1007/BF01314648

Kostolanský F, Varečková E, Betáková T, Mucha V, Russ G, Wharton SA, J. Gen. Virol. 81, 1727-1735, 2000.

Kostolanský F, Mucha V, Slováková R, Varečková E, Acta Virol. 46, 229-36, 2002.

Krammer F, Margine I, Tan GS, Pica N, Krause JC, Palese P, Plos One. 7, e43603, 2012. http://dx.doi.org/10.1371/journal. pone. 0043603
Kreitjtz JHCM, Fouchier RAM, Rimmelzwaan GF, Virus Res. 162, 19-30, 2011. http://dx.doi.org/10.1016/j.virusres.2011.09.022

Kuwano K, Scott M, Young JF, Ennis FA, J. Immunol. 140, 12641268, 1988.

Langley WA, Thoennes S, Bradley KC, Galloway SE, Talekar GR, Cummings SF, Varecková E, Russell RJ, Steinhauer DA, Virology. 39, 321-330, 2010.

Lazarowitz SG, Choppin PW, Virology 68, 440-454, 1975. http:// dx.doi.org/10.1016/0042-6822(75)90285-8

Leikina E, LeDuc DL, Macosko JC, Epand R, Shin YK, Chernomordik LV, Biochemistry 40, 8378-8386, 2001. http://dx.doi. org/10.1021/bi010466+

Lillie JP, Berthoud TK, Powell TJ, Lambe T, Mullarkey C, Spencer AJ, Hamill M, Penng Y, Blais ME, Duncan JA, Sheehy SH, Havelock T, Faust SN, Lambin-Williams R, Glibert A, Oxford J, Dong T, Hill AVS, Gilbert SC, CID 55, 19-25, 2012. http://dx.doi.org/10.1093/cid/cis327

LimAPC, Chan CEZ, Wong SKK, Chan AHY, Ooi EE, Hanson BJ, Virology J. 5, 1-10, 2008.

Lingwood D, McTammey M, Yassine HM, Whittle JRR, Guo X, Boyington JC, Wei CH J, Nabel GJ, Nature 11371, 2012.

Lipatov AS, Gitelman AK, Smirnov YA, Acta Virol. 41, 337-340, 1997.

Loucka J, Schlecht G, Vodolanova J, Leclerc C, Sebo P, Infect. Immun. 70, 1002-1005, 2002.

Luke CJ, Subbarao K, Emerg. Infect. Dis. 12, 66-72, 2006. http:// dx.doi.org/10.3201/eid1201.051147

Maeda T, Ohnishi SFEBSm Letters 122, 283-287, 1980. http://dx.doi. org/10.1016/0014-5793(80)80457-1

Masaki H, Tamura M, Kurane I, Viral Immunol. 13, 73, 2000. http:// dx.doi.org/10.1089/vim.2000.13.73

Mascarell L, Fayolle C, Bauche C, Ladant D, Leclerc C, J. Virol. 79, 9872-9884, 2005. http://dx.doi.org/10.1128/ JVI.79.15.9872-9884.2005

Mbawuike IN, Dillion SB, Demuth SG, Jones CS, Cate TR, Couch RB, Vaccine 12, 1340-1348, 1994. http://dx.doi org/10.1016/S0264-410X(94)80063-6

Mozdzanowska K, Feng J, Eid M, Kragol G, Cudic M, Otvos L, Gerhard W, Vaccine 21, 2616-2626, 2003. http://dx.doi. org/10.1016/S0264-410X(03)00040-9

Mozdzanowska K, Maiese K, Furchner M, Gerhard W, Virology $254,138-146,1999$. http://dx.doi.org/10.1006/ viro.1998.9534

Mozdzanowska K, Zharikova D, Cudic M, Otvos L, Gerhard W, J. Virol. 31, 118, 2007.

Murphy BR and Clements ML, Curr. Top. Microbiol. Immunol. 164, 2635-2643, 1989.

Neirynck S, Deroo T, Saelens X, Vanlandschoot P, Jou, WM, Fiers W, Nat. Med. 5, 1119-1120, 1999. http://dx.doi. org/10.1038/13436

Nobusawa E, Aoyama T, Kato H, Suzuki Y, Tateno Y, Nakajima K, Virology 182, 475-485, 1991. http://dx.doi. org/10.1016/0042-6822(91)90588-3

Norrby E, Gollmar Y, Infect. Immun. 11: 231-239, 1975.

Okuno Y, Isegawa Y, Sasao F, Ueda S, J. Virol. 67, 2552-2558, 1993.

Okuno Y, Matsumoto K, Isegava Y, Ueda S, J. Virol. 68, 517-520, 1994. 
Osterhaus A, Fouchier R, Rimmelzwaan, Phil. Treans. Soc. B 366, 2766-2773, 2011. http://dx.doi.org/10.1098/ rstb.2011.0102

Palese P, Emerg. Infect. Dis. 12, 61-65, 2006. http://dx.doi. org/10.3201/eid1201.051043

Palese P, García-Sastre A, J. Clin. Invest. 110, 9-13, 2002.

Prabhu N, Prabakaran M, Ho Hui-Ting, Velumani S, Qiang J, Goutama M, Kwang J, J. Virol. 83, 2553-2562, 2009. http:// dx.doi.org/10.1128/JVI.02165-08

Préville X, Ladant D, Timmerman B, Leclerc C, Cancer Res. 65,641-649, 2005.

Russ G, Poláková K, Kostolanský F, Styk B, Vančíková M, Acta Virol. 31, 374-386, 1987.

Russ G, Styk B, Poláková K, Acta Virol. 22, 371-382, 1978.

Saikh KU, Martin JD, Nishikawa AD, Dillon SB, Virology 214, 445452, 1995. http://dx.doi.org/10.1006/viro.1995.0055

Sakamoto H, Bellalou J, Sebo P, Ladant D, J. Biol. Chem. 267, 13598-13602, 1992.

Sánchez-Fauquier A, Villanueva N, Melero JA, Arch. Virol. 97, 251265, 1987. http://dx.doi.org/10.1007/BF01314425

Sánchez-Fauquier A, Guillen M, Martin J, Kendal AP, Melero JA, Arch. Virol. 116, 285-293, 1991. http://dx.doi. org/10.1007/BF01319250

Saron MF, Fayolle C, Sebo P, Ladant D, Ullmann A, Leclerc C, Proc. Natl. Acad. Sci. USA 94, 3314-3319, 1997. http://dx.doi. org/10.1073/pnas.94.7.3314

Sebo P, Glaser P, Sakamoto H, Ullmann A, Gene 104, 19-24, 1991. http://dx.doi.org/10.1016/0378-1119(91)90459-O

Schlecht G, Loucka J, Najar H, Sebo P, Leclerc C, J. Immunol. 173, 6089-6097, 2004.

Simsova M, Sebo P, Leclerc C, Int. J. Med. Microbiol. 293, 571-576, 2004. http://dx.doi.org/10.1078/1438-4221-00291

Skehel JJ, Bayley PM, Brown EB, Martin SR, Waterfield MD, White JM, Wilson IA Wiley DC Proc. Natl. Acad. Sci. USA 79, 968-972, 1982. http://dx.doi.org/10.1073/ pnas.79.4.968

Skehel JJ, Wiley DC, Annu. Rev. Biochem. 69, 531-569, 2000. http:// dx.doi.org/10.1146/annurev.biochem.69.1.531

Staneková Z, Mucha V, Sládková T, Blaškovičová H, Kostolanský F, Varečková E, Influenza Resp. Vir. 6, 389-395, 2012. http:// dx.doi.org/10.1111/j.1750-2659.2011.00328.x

Staneková Z, Adkins I, Kosová M, Janulíková J, Šebo P, Varečková E, Antiviral Res. 97, 24-35, 2013 .http://dx.doi.org/10.1016/j. antiviral.2012.09.008

Staneková Z, Varečková E, Virology J. 7, 351-365, 2010. http:// dx.doi.org/10.1186/1743-422X-7-351

Smirnov YA, Lipatov SA, Gitelman AK, Claas ECJ, Osterhaus ADME, Arch. Virol. 145, 1733-1741, 2000. http://dx.doi. org/10.1007/s007050070088

Steel J, Lowen AC, Wang T, Yondola M, Gao Q, Haye K, GarciaSastre A, Palese P, MBio, 1, e00018-10, 2010. http://dx.doi. org $/ 10.1128 / \mathrm{mBio} .00018-10$

Stropkovská A, Mucha V, Fislová T, Gocník M, Kostolanský F, Varečková E, Acta Virol. 53, 15-20, 2009. http://dx.doi. org/10.4149/av 2009 $01 \quad 15$

Struck DK, Hoekstra D, Pagano RE, Biochemistry 20, 4093-4099, 1981. http://dx.doi.org/10.1021/bi00517a023

Styk B, Russ G, Poláková K, Acta Virol. 23, 1-8, 1979.
Sui J, Hwang WC, Perez S, Wei G, Aird D, Chen L, Santelli E, Stec B, Cadwell G, Ali M, Wan H, Murakami A, Yammanuru A, Han T, Cox NJ, Bankston LA, Donis RO, Liddington RC, Marasco A, Nature Struct. Mol. Biol. 1-9, 2009.

Tamura S, Kurata T, Jpn. J. Infect. Dis. 57, 236-247, 2004.

Tamura S, Tanimoto T, Kurata T, Jpn. J. Infect. Dis. 58, 195-207, 2005.

Throsby M, Van den Brink E, Jongeneelen M, Poon LLM, Alard P, Cornelissen L, Bakker A, Cox F, Van Deventer E, Gunan ZI, Cinatla YI, Ter Meulen Y, Lsters I, Carsetti R, Peiris M, De Kruif J, Goudsmit J, PLoS One 12, E3942, 2008. http://dx.doi.org/10.1371/journal. pone. 0003942

Vaccaro L, Cross KJ, Kleinjung J, Straus SK, Thomas DJ, Wharton SA, Skehel JJ, Fraternali F, Biophys. J. 88, 25-36, 2005. http://dx.doi.org/10.1529/biophysj.104.044537

Vanlandschoot P, Beirnaert ER, Barrere B, Calder L, Millar B, Wharton S, Min Jou W, Fiers W, J. Gen. Virol. 79, 17811791,1998

Varečková E, Mucha V, Čiampor F, Betáková T, Russ G, Arch. Virol. 130, 45-56, 1993. http://dx.doi.org/10.1007/ $\underline{\text { BF01318995 }}$

Varečková E, Mucha V, Wharton SA, Kostolanský F, Arch. Virol. 148, 469-486, 2003a. http://dx.doi.org/10.1007/s00705$\underline{002-0932-1}$

Varečková E, Wharton SA, Mucha V, Gocník M, Kostolanský F, Acta Virol. 47, 229-236, 2003b.

Varečková E, Mucha V, Kostolanský F, Gubareva LV, Klimov A, Virus Res. 132, 181-186, 2008. http://dx.doi.org/10.1016/j. virusres.2007.10.004

Wabuke-Bunoti MA, Taku A, Fan DP, Kent S, Webster RG, J. Immunol. 4, 2194-2201, 1984.

Wabuke-Bunoti MAN, Fan DP, J. Immunol. 130, 2386-2391, 1983.

Wang TT, Palese P, Nature Struct. Mol. Biol. 16, 233-234, 2009. http://dx.doi.org/10.1038/nsmb.1574

Wang TT, Tan GS, Hai R, Pica N, Petersen E, Moran TM, Palese P, PLoS Pathog, 6, e1000796, 2010a. http://dx.doi. org/10.1371/journal.ppat.1000796

Wang TT, Tan GS, Hai R, Pica N, Ngai L, Ekiert DC, Wilson IA, García-Sastre A, Moran TM, Palese P, Proc. Natl. Acad. Sci. USA 44, 18979-18984, 2010b. http://dx.doi. org/10.1073/pnas.1013387107

Watowich SJ, Skehel JJ, Wiley DC, Structure 2, 719-731,1994. http:// dx.doi.org/10.1016/S0969-2126(00)00073-3

Webster RG, Brown LE, Jackson DC, Virology 126, 587-599, 1983. http://dx.doi.org/10.1016/S0042-6822(83)80015-4

Weis WI, Brown JH, Cusack S., Paulson JC, Skehel JJ, Wiley DC, Nature 333, 426-431, 1988. http://dx.doi. org/10.1038/333426a0

Wharton SA, Calder LJ, Ruigrok RWH, Skehel JJ, Steinhauer DA, Wiley DC, EMBO J. 14, 240-246, 1995.

Wharton SA, Skehel JJ, Wiley DC, Virology 149, 27-35, 1986. http:// dx.doi.org/10.1016/0042-6822(86)90083-8

White J, Helenius A., Gething MJ, Nature 300, 658-659, 1982. http:// dx.doi.org/10.1038/300658a 0

Wiley DC, Skehel JJ, J. Mol. Biol. 112, 343-347, 1977. http://dx.doi. org/10.1016/S0022-2836(77)80149-6 
Wiley DC, Wilson IA, Skehel JJ, Nature 289, 373-378, 1981. http:// dx.doi.org/10.1038/289373a 0

Wilson IA, Skehel JJ, Wiley DC, Nature 289, 366-373, 1981. http:// dx.doi.org/10.1038/289366a0

Yewdell JW, Gerhard W, Bächi T, J. Virol. 48, 239-248, 1983.

Yewdell JW, Taylor A, Yellen A, Gerhard W, Bächi T, J. Virol. 67, 933-942, 1993.
Yewdell JW, Bennink JR, Smith GL, Moss B, Proc. Natl. Acad. Sci. USA 82, 1785-1789, 1985. http://dx.doi.org/10.1073/ pnas.82.6.1785

Yang J, Li M, Shen X, Liu S,Viruses 5, 352-373, 2013. http://dx.doi. org/10.3390/v5010352

Zhang J, Viruses 4, 2711-2735, 2012. http://dx.doi.org/10.3390/ $\underline{\mathrm{v} 4112711}$ 